\title{
Treatment Results of Dentigerous Cysts Managed by Marsupialisation, Enucleation or Enucleation with Platelet Rich Plasma-a Retrospective Study
}

\author{
Marsupiyalizasyon, Enükleasyon veya Enükleasyon ve Plateletten \\ Zengin Plazma Uygulaması ile Tedavi Edilen Dentijeröz Kistlerin \\ Tedavi Sonuçları: Retrospektif Bir Çalışma \\ (1) Esin Demir ${ }^{1}$, (1) Ömer Günhan ${ }^{2}$
}

'Selçuk University Faculty of Dentistry, Department of Oral and Maxillofacial Surgery, Konya, Turkey

${ }^{2}$ TOBB University of Economics and Technology Faculty of Dentistry, Department of Oral Pathology, Ankara, Turkey

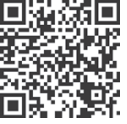

Keywords

Jaw cysts, dentigerous cysts, impacted tooth, enucleation, marsupialisation, platelet rich plasma

Anahtar Kelimeler

Çene kistleri, dentijeröz kistler, gömülü diş, enükleasyon, marsupiyalizasyon, plateletten zengin plazma

Received/Geliş Tarihi : 22.08.2020

Accepted/Kabul Tarihi : 09.01.2021

doi:10.4274/meandros.galenos.2021.86094

Address for Correspondence/Yazışma Adresi: Esin Demir MD,

Selçuk University Faculty of Dentistry,

Department of Oral and Maxillofacial Surgery,

Konya, Turkey

Phone : +905385926810

E-mail : esin_demir88@hotmail.com

ORCID ID: orcid.org/0000-0002-2107-7213

(C) Meandros Medical and Dental Journal, Published by Galenos Publishing House.

This is article distributed under the terms of the

Creative Commons Attribution NonCommercial 4.0

International Licence (CC BY-NC 4.0).

\begin{abstract}
Objective: This study aimed to evaluate the effectiveness of dentigerous cyst treatment with enucleation, marsupialisation or enucleation with platelet rich plasma (PRP) application.

Materials and Methods: The study included 27 cases with dentigerous cysts. Demographic data, treatment modalities, treatment results, size of the bony defect before and after treatment and complications were analysed retrospectively. Patients were separated into three treatment arms. Group 1 comprised 11 patients treated with enucleation, group 2 comprised seven patients treated with enucleation and PRP and group 3 comprised nine patients treated with marsupialisation. Reductions in the size of the radiolucent area at the sixth month follow-up were compared in terms of the vertical and horizontal shrinkage of the lesion and monthly reductions in lesional area.

Results: The treatment results of the three groups were similar. Only the group to which PRP was applied revealed significant vertical shrinkage $(p=0.045)$. Preoperative lesional area and age appeared to be factors significantly affecting bone regeneration $(\mathrm{p}<0.05)$.

Conclusion: Enucleation and marsupialisation are successful treatment modalities for dentigerous cysts. PRP application enhanced bone gain. Marsupialisation enhanced bone integrity and promoted the eruption of permanent teeth.
\end{abstract}

Öz

Amaç: Bu çalışmanın amacı marsupiyalizasyon, enükleasyon, enükleasyon ve plateletten zengin plazma (PRP) uygulaması ile tedavi edilen dentijeröz kistlerin tedavi sonuçlarının karşılaştırmalı değerlendirilmesidir.

Gereç ve Yöntemler: Dentijeröz kiste sahip 27 olgu çalışmaya dahil edildi. Demografik veriler, tedavi şekilleri ve sonuçları, tedavi öncesi ve sonrası kemik defektinin boyutsal ölçümleri ve komplikasyonlar retrospektif olarak analiz edildi. Hastalar 3 farklı tedavi grubuna ayrılarak incelendi. Grup 1 enükleasyonla tedavi edilen 11 hasta içerirken, grup 2 enükleasyon ve kist kavitesine PRP uygulanan 7 hastadan oluşmaktaydı. Üçüncü grup marsupiyalizasyon ile tedavi edilen 9 hasta içermekteydi. Altıncı ayda radyolusent alanda vertikal küçülme, horizontal küçülme ve lezyon alanında aylık küçülme olmak üzere üç parametre şeklinde incelendi. 
Bulgular: Üç grubun tedavi sonuçları benzer çıkarken, PRP uygulanan grup istatistiksel açıdan anlamlı olarak daha hızlı vertikal küçülme sergiledi $(p=0,045)$. Preoperatif lezyon alanı ve yaşın istatistiksel olarak anlamlı bir sonuçla kemik iyileşmesinde etkili bir faktör olduğu görüldü $(p<0,05)$.

Sonuç: PRP kullanımı hem enükleasyon hem marsupiyalizasyon çene kistlerinin tedavisinde başarılı sonuçlar verirken kemik iyileşmesini hızlandırmaktadır. Kemik devamlılığının korunması, kiste eşlik eden daimi dişin sürdürülmesi marsupiyalizasyonla daha kolay sağlanmaktadır.

\section{Introduction}

Odontogenic cystic lesions grow slowly by resorbing the jaw bones. As the cysts enlarge, vital structures may have been damaged, facial asymmetry and displacement of teeth may have developed (1). Dentigerous cysts are the second most common type of odontogenic cysts. It develops around the crown of unerupted tooth caused by expansion of follicle epithelium of unerupted tooth with a well-defined, radiolucent area attached to tooth in cement-enamel junction. Treatment of a dentigerous cyst is dependent on the size of lesion, involved permanent teeth and proximity to anatomic structures (2).

Decompression, marsupialization and enucleation are main treatment modalities for jaw cysts. Enucleation is defined as a complete removal of cystic lining with intention of primary healing. Enucleation of cystic lesions can bring forth risks such as nerve injury or fracture of jaw. To avoid these complications, marsupialization or decompression is recommended to reduce the size of cyst, hence making it safe to enucleate the lesion $(3,4)$. Marsupialization is a technique where a window is created in cystic wall and sutured to the oral mucosa. Decompression is based on a creation of a window between the cyst and oral cavity by fixing a kind of device. Marsupialization and decompression aim to release intraluminal pressure in cyst cavity and gradual decrease in lesion volume (5). Stents, acrylic plates or obturators are used for cyst shrinkage (6).

There are few studies that evaluate bone gain using panoramic views following cyst treatments $(4,6-$ 9). Lesion type, age and preoperative lesion area are investigated if these factors affect the bone gain while performing decompression $(4,6,9,10)$. Researchers also focused on bone regeneration after cystectomy whom analysis were revealed with panaromic radiographs $(11,12)$. Dentigerous cysts, unicystic ameloblastomas, keratocysts were predominantly evaluated to consider lesion shrinkage amount following decompression $(4,6,13)$.
This retrospective study was conducted on cases with dentigerous cysts. The aim of this retrospective study was to compare the effectiveness of only enucleation, enucleation with platelet rich plasma (PRP) application and marsupialization in terms of reduction in cyst dimensions, analyzing the panoramic radiographs acquired pre and post-operatively. Furthermore, the study examined whether lesion shrinkage was related with age and initial lesion size.

\section{Materials and Methods}

A retrospective study was performed involving 27 patients with diagnosis of dentigerous cyst in jaw bones who presented to resercher's private practice from February 2017 to May 2019. Inclusion criterias were having histologically confirmed diagnosis of dentigerous cyst of longer diameter greater than 20 $\mathrm{mm}$ with minimum six months follow-up. Moderate to heavy smokers and medically unfitted patients were excluded.

Histopathological examinations were made after clinical and radiological examination. Histopathological examination revealed lesion with stratified non-keratinized epithelial lining present with a fibrous connective tissue wall mildly infiltrated with inflammatory cells (Figure 1).

Clinical, histopathological, radiological and demographic datas were collected. All ortopantomographies (OPGs) were obtained using the same machine (Promax, Planmeca, Helsinki, Finland).

Different from formula described by Gao et al. (6) the size of cystic lesion was calculated as area of elips before and after treatment on OPG. A standard lesion area was defined as

Lesion area $=\pi \frac{\text { maximal vertical length }(\mathrm{mm})}{2} \frac{\text { maximal horizontal length }(\mathrm{mm})}{2}$

The relative shrinkage size after treatment was measured as the lesion area before treatment minus the lesion area after six months treatment. The relative 
speed of shrinkage of a cystic lesion was calculated as follows:

shrinkage of lesion $=\frac{\text { the lesion area before treatment }- \text { the lesion area six months after treatment }}{\text { duration of treatment ( } 6 \text { months) }}$

Ratio of vertical shrinkage (\%) was calculated as

ratio of vertical shrinkage $=100 \times \frac{\text { preoperative vertical length }- \text { post-operative vertical length after six months }}{\text { preoperative vertical length }}$

Ratio of horizontal shrinkage (\%) was calculated as

ratio of horizontal shrinkage $=100 \times \frac{\text { preoperative horizontal length }- \text { postoperative horizontal length atter six months }}{\text { preoperative horizontal length }}$

Three different treatment protocols have been compared with each other in terms of vertical shrinkage (\%), horizontal shrinkage (\%) and monthly reduction rate of cystic lesion area (relative speed of shrinkage) ( $\mathrm{mm}^{2} /$ month) on OPGs. Preoperative and six months post-operative OPGs of all patients were considered to calculate lesion shrinkage as described in math formulas above. With the aid of statistics we studied whether vertical shrinkage (\%), horizontal shrinkage (\%) or relative speed of shrinkage $\left(\mathrm{mm}^{2} /\right.$ month) had a meaningful correlation with the host factors such as the age of the patient and the initial size of the lesion or treatment modalities.

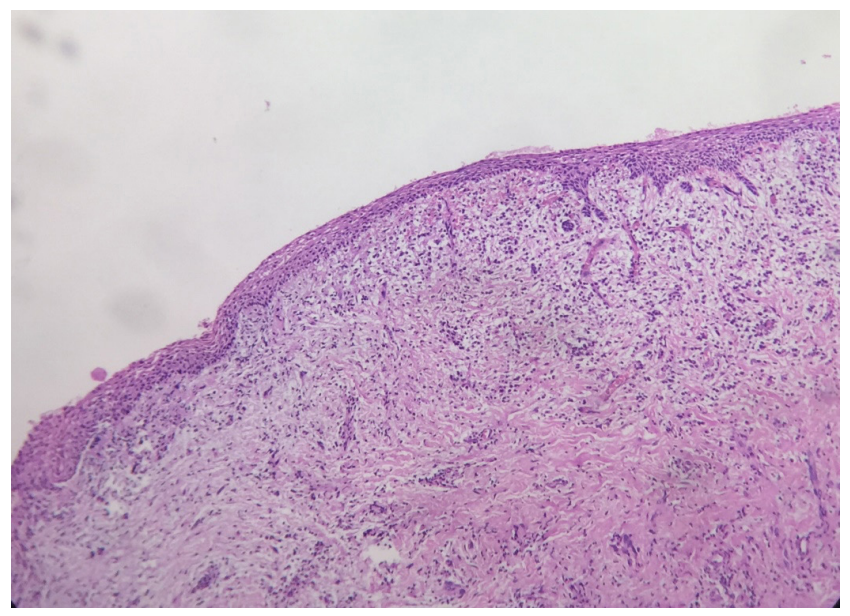

Figure 1. All patients were diagnosed histopathologically. The epitelium was stratified squamous non-keratinized and the subepitelial area showed lenfo-plasmosit infiltrate of chronic type (HEx400)

\section{Treatment Protocol}

Twenty-seven patients with dentigerous cysts were included. All patients signed informed consents before the interventions. This study follows the Declaration of Helsinki. The Ethical Committee of University of İzmir Katip Çelebi approved the study (decision no: 792, date: 02.07.2020). The patients seperated into three treatment arms. Group 1 comprised 11 patients treated with enucleation while group 2 comprised 7 patients treated with enucleation and PRP application. Group 3 comprised 9 patients treated with marsupialization.

Cysts that cause nasal passage obstruction, relatively smaller sized cysts and cysts accompanied by teeth to be extracted were treated with enucleation. Seven patients who were candidates for implant treatment after cyst treatment and close neighborhood to vital structures or roots of teeth were treated with enucleation with PRP application. Larger cysts or cysts that involved permanent teeth to be erupt or anatomic structures were treated with marsupialization. All patients have had panoramic radiographs preoperatively and at post-operative $6^{\text {th }}$ month (Figure 2).

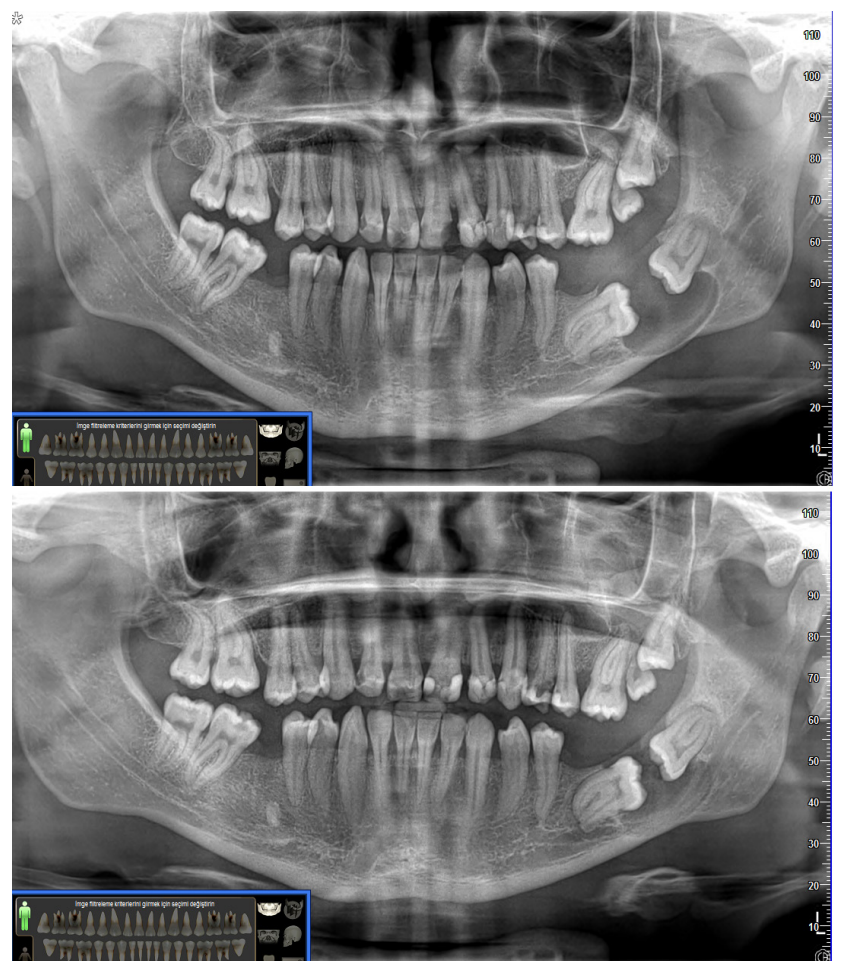

Figure 2. Dentigerous cyst related with kissing molars. A panoramic X-ray taken before marsupialization (a) a panoramic radiograph at $6^{\text {th }}$ month follow up, showing shrinkage of bone cavity 
All treatments were performed under local anesthesia by the same experienced surgeon. Following a careful preparation of a full thickness flap without a perforation or a rupture that may affect the bone healing period, cysts and accompanying teeth were totally removed for group 1.

PRP that derived from the centrifugation of patient's own blood was prepared for group 2. Venous blood was withdrawn from patients and collected in sterile vacuum tube coated with anticoagulant citric acid and dextrose. After first centrifugation under 800 times gravity for 5 minutes, blood was separated into plasma and red blood cells. The red blood cells were removed, and then remaining plasma underwent second centrifugation under 1,500 times gravity for 5 minutes. The bottom layer which was defined as PRP was collected and mixed with calcium chloride to obtain gel form of PRP to facilitate application to cyst cavity. After enucleation of the lesion, PRP was applied to bone cavity before suturation in group 2 . Enucleated cystic lesions were examined histopathologically to confirm clinical diagnosis.

Histopathological analyses were performed with incisional biopsies of cysts at the time of marsupialization for group 3. Cystic lesion opening was sutured to obtain a marsupialization hole after biopsy procedure. Furthermore, an acrylic obturator was planned to keep the lesion uncovered and to avoid food impaction. Dental impressions were taken with silicone and casts were fabricated. Customized Hawley like acrylic plates were fabricated and applied to patients' mouth on seventh day. Until the acrylic obturator was applied to mouth, marsupialization hole was preserved with daily exchanged gauze covered with topical antibiotic pomade. After application of acrylic obturator to mouth, the patients were instructed to maintain overall proper hygiene of the oral cavity through self-irrigation of cavity every day. Cyst openings were prepared like marsupialization hole unlikely to minimal sized decompression holes. However, in our cases we have applied intraoral devices to protect food trap in the cavity and preserve the cyst opening like decompression procedure. Therefore, the marsupialization procedure which we applied to our patients has similarities to decompression procedure. The patients were scheduled for weekly follow-up to provide hygiene of the cyst cavity (Figure 3).
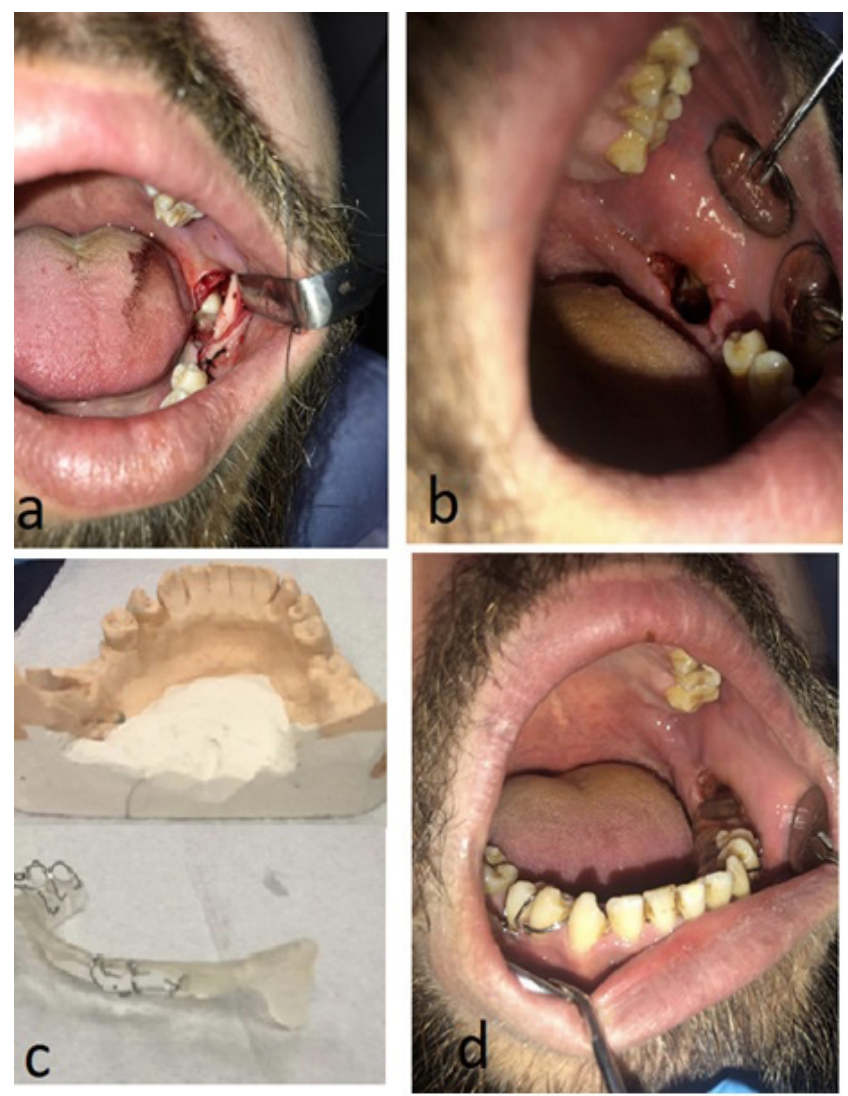

Figure 3. Patient with dentigerous cyst involving kissing molar has been treated with marsupialization. Opening of the cyst and biopsy sampling. [A hole (arrow) was created in bone nearby the window hence mobile soft tissues have been sutured to this hole]. (a) Marsupialization hole was ready a week later, (b) customized Hawley like acrylic obturator, (c) acrylic plate in mouth of patient avoiding trapping of food in the cyst cavity

\section{Statistical Analysis}

Data were recorded using Excel (Microsoft, Redmond, WA) and analysed using SPSS 13.0 (SPSS, Inc, Chicago, IL). Data showed normal distribution according to Kolmogorov-Smirnov and Shapiro-Wilk therefore parametric tests were appropriate for our study. One-Way ANOVA and Pearson correlation analysis were performed. The results were considered significant at a $p$-value lower than 0.05 .

\section{Results}

Twenty-three male and 4 female patients with histopathologically confirmed dentigerous cysts whose ages range between 6 and 71 years (mean: $33.6 \pm 12.1$ ) were included. 
All groups demonstrated significant healing changes over the 6 months of follow-up. The Paired t-test showed a significant difference in terms of vertical length, horizontal length and area of the cyst cavity comparing measurements of before and after treatment on OPG (Table 1). The mean relative speeds of shrinkage ( $\left.\mathrm{mm}^{2} / \mathrm{month}\right)$ of group 1 , group 2 and group 3 were $28.8 \mathrm{~mm}^{2} /$ month, $50.9 \mathrm{~mm}^{2} /$ month, 44.9 $\mathrm{mm}^{2} /$ month, respectively. There was no significant difference among the 3 treatment modalities. Velocity of horizontal shrinkage of group 1, group 2 and group 3 were $32 \%, 50 \%, 43 \%$, respectively. There was no significant difference among the 3 treatment modalities regarding to ratio of horizontal shrinkage. Ratio of vertical shrinkage of group 1, group 2 and group 3 were $37 \%, 57 \%, 54 \%$, respectively. There was a significant difference between group 1 and group 2 (Table 2).

Some of the host factors seemed to contribute to process of bone healing. Ratio of vertical shrinkage was significantly associated with the age of the patient (Table 3). When analyzing the preoperative lesion area, there was a statistically significant correlation with monthly reduction rate (Table 4).

All patients showed good bone healing without any wound dehiscence, although we face with some complications. Three temporary paresthesias were noted in enucleation group that continued for three weeks to three months. Thirteen of cases were originated by third molar teeth. Eight of cases were related with maxillary canine teeth, and remaining cysts of 6 cases were caused by mandibular premolars.

Table 1. Significant difference between preoperative and six months post-operative lesion dimesions in three treatment groups were noted

\begin{tabular}{|c|c|c|c|c|c|c|c|c|c|}
\hline & $\begin{array}{l}\text { Preoperative } \\
\text { Vertical length } \\
\text { (mm) } \\
\text { (mean } \pm \text { SD) }\end{array}$ & $\begin{array}{l}\text { Vertical } \\
\text { length at six } \\
\text { months }(\mathrm{mm}) \\
\text { (mean } \pm \mathrm{SD} \text { ) }\end{array}$ & p & $\begin{array}{l}\text { Preoperative } \\
\text { horizontal } \\
\text { length }(\mathrm{mm}) \\
\text { (mean } \pm \text { SD) }\end{array}$ & $\begin{array}{l}\text { Horizontal } \\
\text { length at } \\
\text { six months } \\
\text { (mm) } \\
\text { (mean } \pm \text { SD) }\end{array}$ & $\mathbf{p}$ & $\begin{array}{l}\text { Preoperative } \\
\text { lesion area } \\
\left(\mathrm{mm}^{2}\right) \\
(\mathrm{mean} \pm \mathrm{SD})\end{array}$ & $\begin{array}{l}\text { Lesion area } \\
\text { at six months } \\
\left(\mathrm{mm}^{2}\right) \\
(\text { mean } \pm \mathrm{SD})\end{array}$ & p \\
\hline Group 1 & $19.8 \pm 2.33$ & $12.6 \pm 2.08$ & 0.000 & $22.2 \pm 1.47$ & 15.3 & 0.000 & $356.7 \pm 55.59$ & $171.4 \pm 40.56$ & 0.000 \\
\hline Group 2 & $16.9 \pm 2.13$ & $7 \pm 1.16$ & 0.001 & $32.3 \pm 5.16$ & 16.6 & 0.000 & $473.9 \pm 128.84$ & $158.4 \pm 47.58$ & 0.011 \\
\hline Group 3 & $23.3 \pm 3.80$ & $11.3 \pm 3.18$ & 0.000 & $27.8 \pm 7.40$ & 16.3 & 0.002 & $562 \pm 193.43$ & $213.6 \pm 100.89$ & 0.007 \\
\hline
\end{tabular}

Group 1 cases treated with enucleation. Group 2 cases treated with enucleation and platelet rich plasma application. Group 3 cases treated with marsupialization. SD: Standard deviation

Table 2. Different treatment groups were compared in terms of monthly reduction in cyst area, ratio of vertical shrinkage and ratio of horizontal shrinkage of cyst dimensions

\begin{tabular}{|l|l|l|l|l|l|l|l|}
\hline & \multicolumn{3}{|c|}{ Group 1 } & \multicolumn{3}{c|}{ Group 2 } & \multicolumn{3}{c|}{ Group 3 } & Mean & p \\
\cline { 2 - 10 } & $\mathbf{n}$ & Mean & $\mathbf{n}$ & Mean & $\mathbf{n}$ & & \\
\hline $\begin{array}{l}\text { Montly reduction in cyst area } \\
\text { (mm²/month) }\end{array}$ & 11 & 28.8 & 7 & 50.9 & 9 & 44.9 & 0.172 \\
\hline Ratio of vertical shrinkage (\%) & 11 & $37 \% \mathrm{a}$ & 7 & $57 \mathrm{~b} \%$ & 9 & $54 \mathrm{ab} \%$ & 0.045 \\
\hline Ratio of horizontal shrinkage (\%) & 11 & $32 \%$ & 7 & $50 \%$ & 9 & $43 \%$ & 0.215 \\
\hline
\end{tabular}

Group 1 cases treated with enucleation. Group 2 cases treated with enucleation and platelet rich plasma application. Group 3 cases treated with marsupialization. $a, b$, ab The difference was significant between $a$ and $b$

Table 3. Relation between age and shrinkage of cyst cavity in three different parameters

\begin{tabular}{|l|l|l|l|l|}
\hline \multicolumn{2}{|c|}{} & Montly reduction in cyst area (mm²/month) & Ratio of vertical shrinkage (\%) & Ratio of horizontal shrinkage (\%) \\
\hline \multirow{2}{*}{ Age } & $r$ & 0.192 & -0.422 & -0.336 \\
\cline { 2 - 5 } & $p$ & 0.337 & 0.028 & 0.086 \\
\hline
\end{tabular}

Group 1 cases treated with enucleation. Group 2 cases treated with enucleation and PRP application. Group 3 cases treated with marsupialization 


\begin{tabular}{|c|c|c|}
\hline & & Montly reduction in cyst area ( $\mathrm{mm}^{2} /$ month) \\
\hline \multirow{3}{*}{ Preoperatif lesion area $\left(\mathrm{mm}^{2}\right)$} & Pearson correlation & $0.779 * *$ \\
\hline & Significant (2-tailed) & 0.000 \\
\hline & $n$ & 27 \\
\hline
\end{tabular}

Sixteen patients revealed complete healing in bone defect during follow up period while the others are ongoing shrinking phase. Also, 5 children with dentigerous cyst related with permanent teeth treated with marsupialization were evaluated in that study. The permanent teeth have given a good response to marsupialization and come towards dental arch.

\section{Discussion}

This study evaluated the healing in dentigerous cysts of jaws to substantiate our understanding of bone healing after enucleation or marsupialization with analysis of OPGs and discussed the indications, treatment results and host factors that affect the bone healing such as age and preoperative cyst size. The patients with odontogenic keratocysts accompanied with or without Gorlin Goltz syndrome, glandular odontogenic cysts, pseudocyts and inflammatory cysts were not included to study. Treatment modalities and growth patterns of pseudocysts are completely different from traditional jaw cysts. Developmental jaw cysts such as keratocysts or glandular odontogenic cysts have an aggressive nature that could affect study results and cause bias of results. Inflammatory jaw cysts such as radicular cyst have an infectious origin that may trigger re-infection during healing period after cyst treatment or apical resections. Therefore, inflammatory cysts could not show a standard healing process due to risk of re-infection. As a result, dentigerous cysts were chosen for this study to understand affective factors on bone healing, since they have been expected to show a standardized healing process.

Enucleation of lesion is an aggressive and fast technique however; it has the risk of compromising important structures nearby. In such cases marsupialization is an alternative that allow the shrinkage of lesion before removal. In both methods, bone gain has occurred. With regard to bone gain after enucleation, different authors have given bone regeneration ratios in cyst cavities at various time periods. Ihan Hren and Miljavec (11) reported 7\%, 27\% and $46 \%$ bone gain in large bone defects after 2, 6 and 12 months, respectively. Chacko et al. (7) reported $25.8 \%, 57 \%$ and $81 \%$ average reduction in size of cysts at post-operative 6 months, 9 months and 12 months, respectively. Chiapasco et al. (14) evaluated both reduction in size and increase in bone density by computed analysis of panoramic radiographs after enucleation of 27 jaw cysts. Mean reduction of cyst cavities were $12 \%, 43.5 \%$ and $81.3 \%$ after 6,12 and 24 months, respectively. In our study, mean vertical reduction in size was $37 \%$ for patients treated with enucleation while mean horizontal reduction in size was $32 \%$ at six months follow up. Bone gain at six months follow-up in our patient population was found slightly higher than that of Ihan Hren and Miljavec's (11) and Chiapasco et al.'s (14) studies. Inconsistency between the results caused by difference between measurement techniques as we evaluated the bony healing with different math formulas. Furthermore, we included patients with only dentigerous cysts; previous studies evaluated inflammatory cysts, keratocysts and even tumoral lesion defects. Lesion type was reported as an affective factor on bone healing (9). Ihan Hren and Miljavec (11) noted that radical approaches to aggressive lesions resulted with removal of cyst walls with part of the surrounding bone wall and lack of bone wall around the defect after operation. However, cystic cavities in our study were surrounded by bone except the most conservative hole that was prepared by surgeon.

The patients who were treated with PRP application after enucleation showed better reduction in cyst cavity in which vertical shrinkage was significantly different from group 1 and 2 . Although, conflicting results were reported about efficacy of PRP on bone regeneration, the use of PRP was reported to have enhanced bone regeneration of 
jaw bone defects such as cleft defects, cyst cavities or segmental defects (15-18). Special attention should be paid to preservation of periosteum which has a critical importance for spontaneous ossification (19). Stabilization of blood clot is another important factor for spontaneous bone regeneration (20). In our study, all cysts were surrounded by bone except the smallest window as possible that was prepared for enucleation during surgery in group 1 and group 2 .

Studies investigating the bone gain with marsupialization or decompression have been published for several times. Articles reporting affective factors on bone gain in jaw cysts were identified via literature search. Various factors such as lesion type, initial lesion area, age of patient and defect configuration have been investigated that have probability to influence effectiveness of treatment $(4,6,9,10,21,22)$. In our study, we have mainly compared different treatment modalities regarding bone gain. Only PRP applied enucleation group showed significantly better healing in term of vertical shrinkage of lesion while patient groups who were treated with only enucleation or marsupialization showed similar bone gain. Also monthly reduction rates of three groups have not showed statistically significant difference. There is limited data of that compares results of different treatment modalities, enucleation and marsupialization on bone gain.

Preoperative lesion area is statistically significant factor in bone healing according to our study. Anavi et al. (10) investigated relationship between lesion shrinkage and preoperative lesion size in a population of 57 cases with dentigerous cyst, keratocyst, radicular cyst and glandular odontogenic cyst who were treated with decompression and resulted that larger lesions showed faster shrinkage. Other studies have also supported that initial lesion area is a significantly affective factor on bone healing period $(6,9,10,22)$. Age was a significant factor on the vertical shrinkage while correlation values were not statistically significant regarding horizontal shrinkage and monthly reduction rate of cyst lesion in our study. Age was reported as an affective factor on bone healing following jaw cyst treatment in some studies $(4,6,10)$. In contrary, age was reported not to have a significant effect on bone healing by some researchers $(9,21,22)$. Lesion type has been reported as an ineffective factor on bone gain by several researchers. Keratocyst, radicular cyst, dentigerous cyst, unicystic ameloblastoma showed similar speed of bone regeneration during marsupialization $(4,6,10)$. In contrary, some studies claimed that the lesion type affect the bone healing $(9,22)$. In our study, we included the cases of dentigerous cysts to evaluate the effect of treatment modalities on bone gain. Dentigerous cyst is defined as a developmental jaw cyst associated with a crown of unerupted or impacted tooth. Mandibular third molars, maxillary canines, mandibular premolars are involved teeth by dentigerous cysts (2). In our study, 14 impacted mandibular third molar (one case with kissing molar), 8 maxillary canines, 6 mandibular premolars with dentigerous cysts (total 28 teeth in 27 cases) were included.

Many researchers have attempted grafting cyst cavities with autogenous bone or bone substitutes. Bicsak et al. (23) supported ß-tricalcium phosphate application to cyst cavities since it is claimed to facilitate the bone healing. Autologous grafting after enucleation accelerated defect ossification. Missing of cortical borders or defects with periosteal covering are leading factors for using additional grafts (20). In our study even large cyctic lesions that are included to study have intact cortical walls, even though the cyst walls thin out by cyst pressure. Therefore additional bone grafts have not been preferred. Instead of grafts, PRP that could be easily obtained from patient's blood without extra charge was used in group 2. Nagaveni et al. (16) supported PRP application to cyst cavities since it has been claimed to have significant effect on bone healing of 10 patients with jaw cyst. Subramaniam et al. (24) have used PRP in traumatic bone cyst cavity. PRP related studies were predominantly runon animal models and have been used with graft materials in cyst cavities of human beings (24-28). Pappalardo and Guarnieri (27) reported histological analysis of cyst cavities augmented with PRP and bovine xenograft and concluded that this combination served promoted bone regeneration. Although, some researchers have shown no benefit of PRP on bone formation $(15,26)$, some reports have confirmed the effectiveness of PRP in enhancing bone regeneration. $(29,30)$. PRP was observed to accelerate bone healing in term of vertical shrinkage in cyst cavity according to our study.

Rahpeyma and Khajehahmadi (31) have reported indications and results of marsupialization in jaw 
cysts. Large cysts, cysts with permanent tooth to be erupted were good candidates to marsupialization. Ugurlu et al. (32) performed decompression for 34 patients with dentigerous cysts related with permanent teeth and reported successful results. In our study, the patients with the similar indications were treated with marsupialization, as a result neurovascular bundle had been protected, tooth loss had been reduced, and permanent teeth come closer to dental arch. Although, permanent teeth that are located in cyst cavity come to a better position with marsupialization, further orthodontic treatment may be required (32). Customized thermoplastic resin stents (6), serum sets, dentures, acrylic devices (31), syringe needle cover (13), decompression stent (33) were reported as marsupialization equipment. In our study, we have used Hawley like acrylic plate which offer stable and comfortable equipment in the mouth of the patient. Requirement of patient compliance to device in the mouth is a drawback of the marsupialization technique.

OPGs have been used to follow the healing of jaw cysts and measure the efficacy of treatments by many researchers $(6,7,9-11,13,14)$. In our study, we have used OPGs to measure reduction in size of cyst cavities in three different parameters; vertical diameter, horizontal diameter and the area of cyst. We calculate the area of cyst using the formula of area of ellipsoid. Gao et al. (6) used a different way to calculate the cyst area (vertical diameter $\times$ horizontal diameter). Since cysts have ellipsoidal shape, our calculation method gives more precise results. Although, OPG is widely used tool in that area, it has some drawbacks as it is a kind of two dimentional imaging. There are limited studies which used computed tomographies or cone beam computed tomographies and calculated the volume of lesion in three dimensions (21).

\section{Conclusion}

The present study showed that enucleation and marsupialization have given similar bone regeneration speed while PRP application has accelerated the bone healing. Although, retrospective nature of this study, standardization of the procedures in terms of treatment protocols, imaging, measurements, follow up periods that was applied to the patients included makes our results valuable. This study is one of the rare studies that compare marsupialization and enucleation. However, controlled prospective studies on larger population are needed to understand effect of treatment methods on bone regeneration better.

\section{Ethics}

Ethics Committee Approval: The Ethical Committee of University of İzmir Katip Çelebi approved the study (decision no: 792, date: 02.07.2020).

Informed Consent: All patients signed informed consents before the interventions.

Peer-review: Externally peer-reviewed.

\section{Authorship Contributions}

Concept: E.D., Design: E.D., Supervision: E.D., Fundings: E.D., Materials: E.D., Ö.G., Data Collection or Processing: E.D., Ö.G., Analysis or Interpretation: E.D., Ö.G., Literature Search: E.D., Writing: E.D., Critical Review: E.D., Ö.G.

Conflict of Interest: No conflict of interest was declared by the authors.

Financial Disclosure: The authors declared that this study received no financial support.

\section{References}

1. Ziccardi VB, Eggleston TI, Schneider RE. Using fenestration technique to treat a large dentigerous cyst. J Am Dent Assoc 1997; 128: 201-5.

2. Rajasekharan A, Thomas SA, Prasad TS, Balan A, Sreedevi PU. Dentigerous cyst of Jaws: Clinico- pathological-imaging correlations of two cases. Journal of Oral Medicine, Oral Surgery, Oral Pathology and Oral Radiology 2019; 5: 132-5.

3. Pogrel MA. Decompression and marsupialization as a treatment for the odontogenic keratocyst. Oral Maxillofac Surg Clin North Am 2003; 15: 415-27.

4. Park HS, Song IS, Seo BM, Lee JH, Kim MJ. The effectiveness of decompression for patients with dentigerous cysts, keratocystic odontogenic tumors, and unicystic ameloblastoma. J Korean Assoc Oral Maxillofac Surg 2014; 40: 260-5.

5. AboulHosn M, Noujeim Z, Nader N, Berberi A. Decompression and Enucleation of a Mandibular Radicular Cyst, Followed by Bone Regeneration and Implant-Supported Dental Restoration. Case Rep Dent 2019; 2019: 9584235.

6. Gao L, Wang XL, Li SM, Liu CY, Chen C, Li JW, et al. Decompression as a treatment for odontogenic cystic lesions of the jaw. J Oral Maxillofac Surg 2014; 72: 327-33.

7. Chacko R, Kumar S, Paul A, Arvind. Spontaneous Bone Regeneration After Enucleation of Large Jaw Cysts: A Digital Radiographic Analysis of 44 Consecutive Cases. J Clin Diagn Res 2015; 9: 84-9.

8. Oh JS, You JS, Kim SG. Clinical and histomorphometric evaluation of decompression followed by enucleation in the treatment of odontogenic keratocyst. J Dent Sci 2018; 13: 329-33. 
9. Oliveros-Lopez L, Fernandez-Olavarria A, Torres-Lagares D, Serrera-Figallo MA, Castillo-Oyagüe R, Segura-Egea JJ, et al. Reduction rate by decompression as a treatment of odontogenic cysts. Med Oral Patol Oral Cir Bucal 2017; 22: 643-50.

10. Anavi Y, Gal G, Miron H, Calderon S, Allon DM. Decompression of odontogenic cystic lesions: clinical long-term study of 73 cases. Oral Surg Oral Med Oral Pathol Oral Radiol Endod 2011; 112: 164-9.

11. Ihan Hren N, Miljavec M. Spontaneous bone healing of the large bone defects in the mandible. Int J Oral Maxillofac Surg 2008; 37: 1111-6.

12. Yim JH, Lee JH. Spontaneous bone regeneration after enucleation of jaw cyst: a radiographic analysis. Int J Oral Maxillofac Surg 2009; 38: 566-7.

13. Gaikwad R, Kumaraswamy SV, Keerthi R. Decompression and cystectomy of the odontogenic keratocysts of the mandible: a clinical study. J Maxillofac Oral Surg 2009; 8: 47-51.

14. Chiapasco M, Rossi A, Motta JJ, Crescentini M. Spontaneous bone regeneration after enucleation of large mandibular cysts: a radiographic computed analysis of 27 consecutive cases. J Oral Maxillofac Surg 2000; 58: 942-8.

15. Marukawa E, Oshina H, lino G, Morita K, Omura K. Reduction of bone resorption by the application of platelet-rich plasma (PRP) in bone grafting of the alveolar cleft. J Craniomaxillofac Surg 2011; 39: 278-83.

16. Nagaveni NB, Praveen RB, Umashankar KV, Pranav B, Sreedevi $R$, Radhika NB. Efficacy of platelet-rich-plasma (PRP) in bone regeneration after cyst enucleation in pediatric patients--a clinical study. J Clin Pediatr Dent 2010; 35: 81-7.

17. Tabrizi R, Karagah T, Shahidi S, Zare N. Does platelet-rich plasma enhance healing in the idiopathic bone cavity? A single-blind randomized clinical trial. Int J Oral Maxillofac Surg 2015; 44: 1175-80.

18. Magesh DP, Kumaravelu C, Maheshwari GU. Efficacy of PRP in the Reconstruction of Mandibular Segmental Defects Using Iliac Bone Grafts. J Maxillofac Oral Surg 2013; 12: 160-7.

19. Huh JY, Choi BH, Kim BY, Lee SH, Zhu SJ, Jung JH. Critical size defect in the canine mandible. Oral Surg Oral Med Oral Pathol Oral Radiol Endod 2005; 100: 296-301.

20. Ettl T, Gosau M, Sader R, Reichert TE. Jaw cysts - filling or no filling after enucleation? A review. J Craniomaxillofac Surg 2012; 40: 485-93.

21. Lizio G, Sterrantino AF, Ragazzini S, Marchetti C. Volume reduction of cystic lesions after surgical decompression: a computerised three-dimensional computed tomographic evaluation. Clin Oral Investig 2013; 17: 1701-8.
22. Kubota Y, Imajo I, Itonaga R, Takenoshita Y. Effects of the patient's age and the size of the primary lesion on the speed of shrinkage after marsupialisation of keratocystic odontogenic tumours, dentigerous cysts, and radicular cysts. Br J Oral Maxillofac Surg 2013; 51: 358-62.

23. Bicsak A, Bogdan S, Barabas J, Szabo G. P.082 Medium-term study on filling large bone defects with beta-tricalcium-phosphate (Cerasorb ${ }^{\circledR}$ ). J Craniomaxillofac Surg 2006; 34: 152.

24. Subramaniam P, Kumar K, Ramakrishna T, Bhadranna A. Bone regeneration with plasma-rich-protein following enucleation of traumatic bone cyst. Eur J Dent 2013; 7: 377-81.

25. Camargo PM, Lekovic V, Weinlaender M, Vasilic N, Madzarevic M, Kenney EB. Platelet-rich plasma and bovine porous bone mineral combined with guided tissue regeneration in the treatment of intrabony defects in humans. J Periodontal Res 2002; 37: 300-6.

26. Choi BH, Im CJ, Huh JY, Suh JJ, Lee SH. Effect of platelet-rich plasma on bone regeneration in autogenous bone graft. Int J Oral Maxillofac Surg 2004; 33: 56-9.

27. Pappalardo S, Guarnieri R. Efficacy of Platelet-Rich-Plasma (PRP) and Highly Purified Bovine Xenograft $\left(\operatorname{Laddec}\left({ }^{\circledR}\right)\right)$ Combination in Bone Regeneration after Cyst Enucleation: Radiological and Histological Evaluation. J Oral Maxillofac Res 2013; 4: 3.

28. Talaat WM, Ghoneim MM, Salah O, Adly OA. Autologous Bone Marrow Concentrates and Concentrated Growth Factors Accelerate Bone Regeneration After Enucleation of Mandibular Pathologic Lesions. J Craniofac Surg 2018; 29: 992-7.

29. Hokugo A, Ozeki M, Kawakami O, Sugimoto K, Mushimoto $\mathrm{K}$, Morita $\mathrm{S}$, et al. Augmented bone regeneration activity of platelet-rich plasma by biodegradable gelatin hydrogel. Tissue Eng 2005; 11: 1224-33.

30. Graziani F, Cei S, Ducci F, Giuca MR, Donos N, Gabriele M. In vitro effects of different concentration of PRP on primary bone and gingival cell lines. Preliminary results. Minerva Stomatol 2005; 54: 15-22.

31. Rahpeyma A, Khajehahmadi S. Marsupialization for Treatment of Jaw Cysts: Indications and Limitations. Journal of International Oral Health 2016; 8: 158-62.

32. Ugurlu F, Akyuz S, Mentes A. Outcome of Mandibular Dentigerous Cysts 1 to 10 Years After Decompression Using a Custom-Made Appliance. J Oral Maxillofac Surg 2021; 79: 152-63.

33. Enislidis G, Fock N, Sulzbacher I, Ewers R. Conservative treatment of large cystic lesions of the mandible: a prospective study of the effect of decompression. Br J Oral Maxillofac Surg 2004; 42: 546-50. 